\title{
EDUCATIONAL POLICY IN THE COLONIAL ERA
}

\author{
Lilie Suratminto ${ }^{1}$
}

\begin{abstract}
Since the governance system of Dutch East Indies was applied in 180o, the Colonial Government require chief laborers from pribumi indigenous or native Indonesian people, who were able to read and write well because the number of European personnel was limited at the time. The necessity for unskilled laborers who could read, write and count was increasing due to the enforcement of Cultuur Stelsel. The necessity for administrative staff was also increasing especially in the companies and goverment institution. The goverment, therefore set up Sekolah Ongko Loro to fulfil the first need, and to fulfil the second need, then it was built Sekolah Kelas Satu (First Level School), a school for nobles or government officials. The occurence of national movement triggered the existance of wild schools (wilde scholen) were strictly eradicated by BB (Binnenlands Bestuur) while for Foreign Eastern Echnicity (China, Arabian), were given freedom to set up schools based on their language and culture. However, in those schools, historical lesson was slightly taught because the Government was worried that it would empower nationalism spirit which began to grow everywhere in early $2 O^{\text {th }}$ century.
\end{abstract}

Keywords: pribumi (indigenous people), unskilled laborers, nobles of Robe, First Level School, Second Level School, Wild School.

\footnotetext{
${ }^{1}$ Lilie Suratminto, Lecturer of Dutch Language and Culture in Faculty of Humanities in University of Indonesia and an advisor for the lecture of Dutch Language as the Source of History in History Department in UNJ. For academic interest, the author can be contacted through the office address: Komplek UNJ, Jl. Rawamangun Muka, Jakarta Timur 13220.
} 
LILIE SURATMINO,

Educational Policy in the Colonial Era

\section{Introduction}

1870 was a very important period because in this year horticulture or cultivation of plants (Cultuur Stelsel) was banned by the government of Dutch East Indies. In practice, the Implementation Policy of Cultuur Stelsel was an arbitrary coercion towards the farmers who were the owners of the land by the indigenous sovereign so that they obtained extreme profit from the government of Gubernemen so hard was the coercion that the system was called Cultivation System.

The system which had previously been designed properly suited to the proposal of General Governor Van den Bosch hat was mistakenly used by the indigenous sovereign to enlarge their opportunity to grasp huge profits by suppressing their own people. The Government had been actually noticing these mistakenly practices however they ignored and even closed their sight and to this suppression as the Government precisely advantaged more because the more before industrious the farmers worked, the more they doubled the natural resources which made government obtained bigger profit; as a result of this, foreign exchange flowed remarkably huge to Dutch Government. According to Faseur in Indisch Gasten, the total of the profit was absolutely fantastic and doubled compared to the Plan of National Budget of the Dutch.

It was C.H. van Deventer, a leader triggering a thought of Ethical Policy (Etische Politiek), who wrote De Eereschuld 'Debt of Honor' in 1899. In his article, Deventer stated that the profit obtained by the Dutch should have been paid back to the Dutch East Indies people. And then the term of Etische Politiek 'Ethical Policy' existed. Deventer proposed several matters related to the improvement of the policies of Dutch East Indies administration through setting up education, building irrigation, and planning for transmigration. The three matters had a close correlation to the indigenous people lives. In this paper, it is discuss about the policy of education in Dutch East Indies in the early of 19th century along with the development of Indonesian nationalism spirit.

\section{The Establishment of Schools in the Dutch East Indies}

Since the era of Dutch East Indies colonial administration, there had been built some school. In 1817, in Batavia, it was established a common or a grammar school for the European, Lager Onderwijs en Lagere Scholen voor Europeanen, which was a pioneer of ELS or Europeesche Lagere School. Nevertheless, the implementation ofeducationforindigenouspeoplecouldjust be implemented after King of Netherland passed a Certificate Law No. 95 dated on the 3oth of September 1848. According to the Certificate, the Governor of Dutch East Indies could budget f. 25.000,- annually to the education. In 1849 , there were 20 indigenous schools in each capital city of a province.

The purpose of such education was to accelerate the implementation of Cultuur Stelsel. The students are limited to the children of nobility and functionary. The subjects were given in local language with the materials was about reading, writing and arithmetic. Reading consisted of plain material about the local literature, a little bit about geology, agriculture, and plane 
surveying as well (Kawitama 2013). At that time, this school had graduated cadastres or expert in plant surveying. This was very important because agriculture land required a high accuracy.

In 1852 Kweekschool 'Teacher School' was established in Surakarta, then followed by other regions such as Bukittinggi, Tapanuli, Tondano, Ambon, Probolinggo, Banjarmasin, Makassar and Padang Sidempuan. In 1860 in Batavia Gymnasium Koning Willem III (KW-drie) was established, (now it was in front of Salemba National Library Building), then a high school of Lager Onderwijs en Lagere Scholen voor Europeanen was established too. The length of Study was three years. In 186, this school was divided into two; 5 years and 3 years length. Its purpose was to encourage students to a more continue their study to advance school military, civil servant (ambtenaar) or education of trade and handicraft in Delft, Netherland. This school was furthermore developed into HBS (Hogere Burger School). Indigenous people were eventually allowed to attend this school in 1874.

According to Staatsblad 1893 No. 125, there were two education for indigenous people; De Schoolen der Eerste Klase 'First Level Elementary School) which was intended for nobles and aristocrats. The aim of this education was to fulfill the need for government officials, traders, and entrepreneurs. It was five years lengths of study. Besides reading, writing and arithmetic, the students were also taught geology, history, natural science, drawing, and plant surveying.

De Schoolen der Tweede Klasse 'Sekolang Onko Loro' was for common indigenous people. The length of study was three years and they student were merely taught reading, writing and arithmetic. Furthermore, there was a King's school for education of governmental administration field built in 1876 in Tondano and in 1878, King's School was established in Bandung. In1900 the King's School was changed into OSVIA (Opleiding school Voor Inlandsche Ambtenaren). This school functioned to educated the candidates of government officials and the study took 5 years to be accomplished. In 1927, OSVIA was reorganized into MOSFIA (Middelbare Opleidingschool voor Inlandsche Ambetenaren) taking 3 years length of study. Accomplishing MULO (Meer Uitgebreid Lager Onderwijs) was the absolute requirement of the participants to be able to attend this school.

Unfortunately, in 1811 smallpox epidemic spread severely in Java; henceforth some of the indigenous people to be the cured from the smallpox disease. In medical field government needed indigenous doctors. Not until the 2nd of January 1829, there was training for the smallpox aides improved. This new school was eventually set up in 1851 .

Then, the previous three-year-duration of study for Java Medical School was then changed into 5 to 6 years long in 1875 , using Dutch as the introductory language. Their title was no longer Javanese Doctor but Medical Specialist of Bumi Putera or Inlandsch Geneeskundige. In 1902 the school was again changed into STOVIA 'School tot Opleiding van Indische Artsen'. Furthermore, NIAS (Nederlandsch Indische Artsen School) was established in Surabaya in 1913. 
LILIE SURATMINO,

Educational Policy in the Colonial Era

\section{The Education during the Ethical Policy Period}

Due to the pressure party in the Dutch Parliament, then some alterations were carried out in the policy of Dutch East Indies towards indigenous people. In 1907 there were two essential policies passed in Staatsblad 1907, the establishment of two kinds of school for indigenous people consisting of First Class School Dutch characterized and a Dessau school. There was an alteration in the First Class School, it was the conferral of Dutch language in the third year of study. In the sixth year, Dutch language was utilized as introductory language. The duration of study in First Class School was seven years long. First Class School was shifted in 1914 to be HIS (Hollands Inlandsche School). The students were from the noble class.

The second alteration was to establish a village school. Because the Second Class School was an expensive school, since its operation required an absolutely big budget, in 1907 it was established a village school in which the teachers are appointed by the villages themselves and they were not civil servants. Henceforth, there were three categories, they were village school for the villagers, Second Class School or Vervolg School and First Class School then changed into HIS.

\section{Kinds of Schools during Colonial Period}

Schools during colonial period were generally classified according to the social descendants and social structures. The first one was Low School (Lager Onderwijs) using Dutch language as the introductory language, are as follows;
- ELS (Europeesche Lagere School) established in 1818 was intended to the children descendants of Europe and Foreign Eastern or Bumi Putera from the prominent figures. The length of study was 7 years.

- HCS (Holland Chinese School) established in 1908 was intended to the children descendants of Foreign Eastern, the length of study was 7 years.

- HIS (Holland Inlandsche School) was a low school for the native people of Indonesia which was generally intender for the children of nobles, prominent figures and civil servants (ambtenaar).

- School of Bumi Putera Tweede Klasse. This school was intended for the children of indigenous people, the length of study was 7 years and was established in 1892.

- VillageSchool(Volksschool)established in 1907 was intended for Bumi Putera people which took 7 years of study.

- Advanced School (Vervolgsschool) established in 1914 was intended for Bumi Putera people.This was the high school of Village School.

- Transitional School (Schakelschool) was a transition of Village School with three-year long of study in the primary level using Dutch language as an introductory language. The length of study was 5 year and was intended for the children of Bumi Putera.

In addition to those schools, there were still special schools and then were ethnically characterized which affiliated into HIS (Holland Inlandsche School), such as Ambonsche Burgerschool and 
Hoofdensschool (schools for children of noble class).

From the elementary school there were still advanced schools called high schools mentioned as follows;

\section{MULO-Meer Uitgebreid Lagere School.}

2. AMS - Algemene Middelbare School.

3. HBS - Hogere Burger School.

Besides those schools, there were also vocational schools, i.e.:

\section{Ambachts Leergang 'School of Craftsmanship'}

2. Ambachtsschool 'School Craftsmanship'

3. Technisch Onderwijs 'School Engineering'

4. Handels Onderwijs 'School of Trade (Economy)'

5. Landbouw Onderwijs 'School of Agriculture'

6. Meisjes Vakonderwijs 'School of Female Skill'

7. Kweekschool 'School of Teachership'

a. Normaalschool 'Public School'

b. Kweeksschool 'School of Teachership'

c. Hollandsschool, Inlandsschool, Kweekschool 'Dutch School, Bumi Putera School, School of Teachership',

After the completion of the high school, there were also universities established due to the requirement of specialists availability;

a. Technische Hoge School.

b. Rechtskundige Hoge School. c. STOVIA (Medical School).

d. Geneeskundige Hogeschool (Medical University).

\section{Wilde Scholen or Wild schools and nationalism spirit}

From the above discussion it was obviously seen the effort of colonial administration to established various education to improve indigenous people's knowledge; nonetheless, there was something eye-catching that Colonial Administrator applied a strict discrimination. People who could earn adequate education and sufficient facilities were only children of the nobles and government officials.

In addition, the subjects taught were greater in number than that of schools for indigenous class. It was so contrastive that the masses of common people could only earn knowledge and school in the second class schools (ongko loro) in the village or dessa school, where the subjects learned merely about emphasizing on mastery in simple reading, writing and plain arithmetic. That was aimed for practical purposes correlated closely to their daily occupation involving the majority of farmers, unskilled laborers or micro traders.

Since the foundation of Boedi Oetomo, the nationalism awareness of Indonesia was growing stronger, even stronger when they were able to read and write. The indigenous also realized the high expense of education; therefore there was a big difference of education intended to the nobles and the functionary, they also realized they got much difference of education they earned than those of the 
children of nobles' and the functionaries' In fact it was true that earning such education intended to the nobles of the Robes, nobles and functionaries expended a high cost, henceforth there had been efforts from many sides to establish indigenous schools whith expended far more cheaply expense. Noticing the growth of indigenous schools that they called wilde scholen or wild schools, the government were worried as they realized that if the entire common people who were great in number had higher education, they wouldn't be eager to be unskilled laborers. Therefore, the officials of BB (Binnenlands Bestuur 'Local Government') struggled hard to eradicate those wild schools.

Through the opening of schools of which introductory language was Dutch, it was molded the young Indonesian intellectuals who were previously expected to sustain the continuity of Colonial Administration. However, many of the alumni began to realize the integrity of their nationality as well as their self-esteem as human being who had equal rights and degree in this Earth. Seeing the discrepancy and injustice done by the Colonial Sovereignty, they were awakened and eventually their nationalism spirit started to grow exuberantly. Started by the lofty ideals of Boedi Oetomo, massed organizations were emerging just like mushrooms in rainy season.

There were many school founders were arrested and adjudicated, including nationalist leaders of Wilde Scholen such as Djojo Poespito and his wife, Suwarsih Djojopoespito. Realizing that the circumstance of education which was getting severe when RM Soewardi
Soeyaningrat was exiled to Netherland along with Tjipto Mangoenkoesoemo and Dauwes Dekker, RM Suwardi decided not to continue his medical school and decided to continue his study to the education field, and finally he graduated and got his certificate of MO (MO-Certificate).

Onderwijs is diploma dat
bevoegdheid geeft om les te geven
in de onderbouw van he secundair
onderwijs ['. . MO Certificate
was a Certificate of High School
Education, a certificate giving an
authority to pioneer pedagogy in
Secondary Level'] (Van Dale 2005:
2178).

MO certificate was obliged to be owned by people who were eager to manage education. Therefore, having returned to Dutch East Indies, he established a school named Sekolah Taman Siswa and at once changed his named becoming Ki Hadjar Dewantoro without any nobility title. He was throughly populist and it made BB could not do anything to stop him because the establishment of Taman Siswa School was legitimate under the laws.

Through the establishment of Taman Siswa, the pioneers of nationalism spirit were growing more exuberantly in Dutch East Indies. It was a starting point of the growth of national heroes who then share big contributions in fighting for Indonesian Independence to chase away colonialism, chase the colonialism away from the motherland of Dutch East Indies which later changed into The Republic of Indonesia. 


\section{Conclusion}

The education policies in colonial era tended to be discriminative in nature. It could be understood, because at the time companies and the government of Dutch East Indies required Human Resources from common or indigenous people to be arbeiders 'the unskilled laborers' who only needed practical knowledge and they were also great in number with a very low payment or wage.

They were called 'wong cilik' or the low. The demand of their livelihood was still plain, it was only for food, clothing and houses. For the level of governmental administration, Human Resources required by government were less in number than those of unskilled labors, therefore government would appoint them from the nobles and government functionaries as ambtenaar or 'government officials'. They were taught to manage administrative matter accurately and neatly. They were noble of Robes.

They worked in a relaxed way, lived peacefully with a little pressure in enforcing their daily duties. Meanwhile for the ethnical of China and Arabian or Japan, they were included into Foreign East, they were given freedom in earning their education because after graduating they used to work in private companies or their own companies. Henceforth, the government generally interfered them slightly or even government didn't interfere at all because they could afford their education themselves. The government merely directed equalities in curriculum and local content subject suited to the need of their own ethnics. It seemed that history subject was a very cautious subject one for them and it was only intended for schools of European, because colonial government were worried the European Struggle such as French Revolution which imbued indigenous people to prosecute the equality of human right. As a result, the government merely emphasized the domestic history like some folks and local legends. []

\section{REFERENCES}

Adam, A. W. (2007). Seabad Kontroversi Sejarah. Yogyakarta: Ombak

Ankersmit, F.R. (1987). Refleksi Tentang Sejarah. Terjemahan. Jakarta: PT. Gramedia

Bakker, J.W.M. (1984). Filsafat Kebudayaan. Yogyakarta: Tanpa penerbit

Bernes, H. F. (1962). A History of Historical Writing. New York : Dover Publications, Inc

Easton, S. C. (1960). The Heritage of the Past. New York

Fansevis, P. W. (1959). Asal-usul Peradaban Timur. Jakarta: Kinta.

Geertz, C. (2000). Negara Teater Kerajaan-Kerajaan di Bali Abad Kesembilan Belas. Terjemahan, Yogyakarta : Bentang Budaya.

Kartodirdjo, S. (1990). Pengantar Sejarah Indonesia Baru: Sejarah Pergerakan Nasional. Jakarta : PT. Gramedia.

Kiwatama. (2011). Perjalanan Pendidikan abad XIX in http://kiwatama. wordpress.com/2011/o6/10/ perjalanan-pendidikan-abad-xix/ uploaded on the 26th of April 2013 
Mestoko, S. dkk. (1986). Pendidikan di Indonesia dari Jaman ke Jaman. Jakarta: Balai Pustaka. pg. 102-103.

Notosusanto, N. (1993). Sejarah Nasional Indonesia III, IV, V. Jakarta: Balai Pustaka.

Ricklefs. M. C. (2001). Sejarah Indonesia Modern 1200-2004. et al. Jakarta : PT. Serambi Ilmu Semesta.

Siswanto, et.al.(1992).Penafsiran Sejarah. Malang:PPPGIPS

Soekmono. (1973). Pengantar Sejarah Kebudayaan Indonesia 1, 2, dan 3. Yogyakarta: Kanisius.

Tim penulis. (1993). Sejarah Pendidikan di Indonesia di Jaman Penjajahan. Jakarta: Departmen Pendidikan dan Kebudayaan, Direktorat Sejarah dan Nilai Tradisional. Inventory Projek.
Toynbee, A. (1988). A Study of History, The One-Volume Edition Illustrated. London: Oxford University Press and Thames and Hudson Ltd.

Van Peursen, C.A. (1993). Strategi Kebudayaan. Yogyakarta:Kanisius

Van Dale. (2005). Groot Woordenboekvan de Nederlandse Taal. By T. van den Toorn dkk (eds). Utrecht/Antwerpen: Ed. 14.

Wasito, W.(2000).Kamus UmumBelandaIndonesia. Jakarta: van Hoeve.

Wijda, I. G. (2002). Menuju Wajah Baru Pendidikan sejarah. Yogyakarta: Lapera Pustaka Utama

Wiriatmadja, R. (2001). Pendidikan Sejarah di Inonesia Perpektif Lokal, Nasional dan. Global. Bandung: Historia Press Utama 